\title{
Involvement of simultaneous multiple transcription factor expression, including cAMP responsive element binding protein and OCT-1, for synovial cell outgrowth in patients with rheumatoid arthritis
}

Sueshige Wakisaka, Noboru Suzuki, Mitsuhiro Takeno, Yuko Takeba, Hiroko Nagafuchi, Nobuhiko Saito, Hideo Hashimoto, Tetsuya Tomita, Takahiro Ochi, Tsuyoshi Sakane

Departments of Immunology and Medicine S Wakisaka N Suzuki

M Takeno

Y Takeba

H Nagafuchi

T Sakane

and Department of Internal Medicine N Saito

St Marianna University School of Medicine, Kawasaki, Kanagawa, Japan

Department of Orthopaedic Surgery, Osaka University School of Medicine, Osaka, Japan H Hashimoto

$\mathrm{T}$ Tomita

T Ochi

Correspondence to: Dr T Sakane, Departments of Immunology and Medicine, St Marianna University School of Medicine, 2-16-1, Sugao, Miyamae-ku, Kawasaki, Kanagawa 216, Japan.

Accepted for publication 21 May 1998

\begin{abstract}
Objective-To elucidate possible roles of several transcription factors in the pathogenesis of rheumatoid arthritis (RA), the transcription factor expression in RA synovial tissue and their contribution to RA synovial cell functions were studied. Methods-Single cell suspension of dissociated synovial tissue was cultured to induce in vitro tissue outgrowth of RA synovial cells. Transcription factors were immunohistochemically identified in RA synovial tissue obtained by joint surgery and in the in vitro tissue outgrowth, and confirmed by western blotting and gel shift assays.

Results-Immunohistochemical examination of RA synovial tissue revealed simultaneous expression of various transcription factors (NF-кB, c-Jun (a component of AP-1), cAMP responsive element binding protein (CREB), and OCT-1). The same set of transcription factors was expressed in the in vitro tissue outgrowth of RA patients. The early passage RA synovial cells were treated with interleukin $1 \beta$ (IL1ß) and confirmed translocation of transcription factors into the nucleus by western blotting, and their DNA binding activity by gel shift assays. Conclusion-This study emphasises the importance of the simultaneous expression of several transcription factors for the hyperactivity of $R A$ synovial cells that leads to tissue outgrowth.

(Ann Rheum Dis 1998;57:487-494)
\end{abstract}

Rheumatoid arthritis (RA) is a chronic inflammatory disorder characterised by proliferative and invasive synovitis. Initial histological features of RA are synovial lining hyperplasia, excessive angiogenesis, and accumulation of mononuclear cells including $\mathrm{T}$ lymphocytes in the synovium. ${ }^{1-4}$ It should be emphasised that both macrophage-like synovial cells residing in the lining layer of synovium and fibroblast-like synovial cells locating in the intimal lining layer are increased in the synovial tissue of RA patients.

It is evident that excessive production of proinflammatory cytokines such as tumour necrosis factor $\alpha(\mathrm{TNF} \alpha)$ and interleukin $1 \beta$ (IL1 $\beta$ ) in the joints leads to the increased pro- liferation of RA synovial cells mostly in an autocrine or paracrine fashion, or both, ${ }^{4}$ resulting in the formation of pannus that causes damage of articular cartilage. ${ }^{5-10}$ Although the exact cause of the pathological processes in this chronic inflammatory joint disease is not fully understood, abnormal proliferation of, and excessive production of proinflammatory cytokines by synovial cells are intimately associated with the development of RA. ${ }^{11} 12$

Gene transcription is tightly regulated by various mechanisms in eukaryocytes. ${ }^{13}{ }^{14}$ Transcription factors are involved in the control of gene transcription. ${ }^{15-17}$ Indeed, transcription factors may regulate cytokine production, tissue degrading proteinase production, and synovial hyperplasia in patients with RA. It has recently been reported that NF- $\mathrm{NB}$ and $\mathrm{AP}-1$ are involved in the hyperactivity of RA synovial cells. ${ }^{18-21}$ In addition, it is known that transcription factors not only regulate various aspects of cell activation but also are the potential targets of therapeutic intervention in patients with RA.

Therefore, in this study, we focused our attention on the expression of $\mathrm{NF}-\kappa \mathrm{B}, \mathrm{AP}-1$, cAMP responsive element binding protein (CREB), and OCT-1 of both RA synovial tissue and RA synovial cell outgrowth resembling pannus that developed after a long term in vitro culture.

\section{Methods}

PATIENTS

A total of 22 patients with RA, as defined by the revised criteria of the American College of Rheumatology ${ }^{22}$ were recruited into the study. The characteristics of the patients (two men, 20 women) were their mean (SD) age was 54.6 (13.7) years and all were positive for rheumatoid factors. Most of the patients were receiving non-steroidal anti-inflammatory drugs. They had not been treated with either high doses of corticosteroids, cytotoxic drugs or immunosuppressive agents. Approval was obtained from the human studies committee and individual informed consent from each patient was obtained before we conducted this study. Four patients with osteoarthritis (OA) (mean (SD) age 74.7 (1.2) years) were included as a disease control in this study.

Synovial tissues were obtained from the joints of patients undergoing joint replacement or synovectomy of various joints. The procedures 
were knee synovectomy in seven patients, wrist synovectomy in three, and total knee replacement in 12. Thickened villous synovial tissue was recovered for the experiments. Haematoxylin and eosin staining of the tissues revealed that the synovial tissues were grossly thickened and there were moderate diffuse infiltration of chronic inflammatory cells into the synovium; proliferation of blood vessels and of synovial fibroblasts was present (in some cases, marked) in areas of cellular infiltration and was accompanied by multiplication and enlargement of synovial lining cells (data not shown).

MEDIA

Media used in this study were Iscove modified Dulbecco medium (IMDM; Flow Laboratories Inc, Rockville, MD) containing penicillin $(100 \mu \mathrm{g} / \mathrm{ml})$ and streptomycin $(100 \mathrm{U} / \mathrm{ml})$ (Life Technologies, Inc, Tokyo, Japan) and 10\% fetal calf serum (FCS) (Life Technologies, Inc).

FIBROBLAST-LIKE SYNOVIAL CELL LINES

We obtained synovial tissues from patients with RA undergoing joint surgery, and thickened villous synovial tissue was aseptically recovered for the experiments. Synovial tissue cells were isolated by enzymatic dispersion of the synovial tissues. ${ }^{24}$ The tissues were minced and incubated with $1 \mathrm{mg} / \mathrm{ml}$ of collagenase for two hours at $37^{\circ} \mathrm{C}$ in serum free IMDM, followed by trypsin treatment for one hour. Thereafter, the cells were cultured at $2 \times 10^{4}$ cells $/ \mathrm{ml}$ in IMDM with $10 \%$ FCS overnight. ${ }^{24}$ Nonadherent cells were removed. Adherent cells were subsequently harvested from the plates using trypsin/EDTA, and cultured in the medium. At confluence, cells were trypsinised, split at a 1:3 ratio, and recultured in the medium. Fibroblast-like synovial cells were used from passages 4 to 8 in these experiments, during which time they became a homogeneous population of fibroblast-like synovial cells. These cells were positive for VCAM-1 expression, suggesting that the cells are derived from the intimal lining. ${ }^{7}$ We established 22 independent fibroblast-like synovial cell lines from the synovium of 22 patients with RA.

The fibroblast-like synovial cells were grown to confluence as judged by phase contrast microscopy, and the medium was first changed to IMDM $+0.25 \%$ FCS to establish quiescence. Cells were stimulated to resume growth with IMDM supplemented with $10 \%$ FCS and were used for the experiments.

\section{DEVELOPMENT OF IN VITRO SYNOVIAL CELI}

OUTGROWTH

Synovial tissue cells were isolated by enzymatic dispersion of the synovial tissues as described above. Dissociated synovial cell preparations containing $\mathrm{T}$ cells, macrophage-like synovial cells, and fibroblast-like synovial cells were cultured in the 24 well plate, as reported by Holoshitz et al..$^{23} \mathrm{~A}$ half volume of the culture medium was replaced twice a week. In some experiments, recombinant IL2 (Ajinomoto, Inc, Tokyo, Japan) and/or purified protein derivatives of Tuberculosis (PPDs; Kyowa Pharmaceutical Industries, Inc, Tokyo, Japan) were introduced into the culture. The addition of IL2 and/or PPDs into the culture resulted in the earlier appearance of the visible tissue outgrowth. Nevertheless, there were no histological differences between the outgrowths developed in the medium alone and those developed in the presence of IL2 and/or PPDs (data not shown).

\section{ABs AND REAGENTS}

Normal rabbit IgG, normal mouse IgG, anti-NF- $\kappa \mathrm{B}$ p65 Ab (Rockland, Inc, Gilbertsville, PA), anti-NF- $\mathrm{KB}$ p50 Ab (Rockland, Inc), anti-c-Jun Ab (c-Jun specific; Santa Cruz Biotechnology, Inc, Santa Cruz, CA), anti-CREB $\mathrm{Ab}$ (Upstate biotechnology, Lake Placid, NY), and anti-OCT-1 Ab (Upstate biotechnology) were used in immunohistochemical staining and western blotting analysis. Recombinant IL1 $\beta$ (Boehringer Mannheim, Gmbh, Mannheim, Germany) was used in this study. $\mathrm{N}$-acetyl-L-cystein (NAC), and dexamethasone were purchased from Sigma Chemical Co (St Louis, MO). ${ }^{25} 26$ Adenosine-3', 5'-cyclic monophosphorothioate, Rp-isomer (MW, 446.5; Rp-cAMP) was obtained from Biolog Life Science Institute (Bremen, Germany). ${ }^{27}$ Rp-cAMP was initially diluted in phosphate buffered saline (PBS) to $1 \mathrm{mM}$, filter sterilised, and stored at $-20^{\circ} \mathrm{C}$ until use. We used the non-toxic concentrations of these compounds, as have been reported..$^{25-27}$

\section{PROLIFERATION ASSAY}

Triplicate cultures in 96 well flat bottomed microtitre plates (Costar Data Packaging Corp, Cambridge, MA) of $5.0 \times 10^{3}$ synovial fibroblast-like cells were established in a total volume of $200 \mu \mathrm{l}$. The synovial cells were cultured for seven days in the presence or absence of various substances. Proliferative response was measured by the incorporation of $\left[{ }^{3} \mathrm{H}\right]-\mathrm{TdR}(1 \mu \mathrm{Ci} /$ well; Amersham International, Buckinghamshire, England) during the last 16 hours of the cultures. ${ }^{28}$

NUCLEAR EXTRACTS AND GEL SHIFT ASSAYS Nuclear proteins were prepared as described. ${ }^{29}{ }^{30}$ Briefly, cells were resuspended in buffer A (10 mM N-2-hydroxyethylpiperazine$N^{\prime}$-2-ethanesulphonic acid (HEPES); pH 7.9, $1.5 \mathrm{mM} \mathrm{MgCl}_{2}, 10 \mathrm{mM} \mathrm{KCl}, 0.5 \mathrm{mM}$ DTT, $0.5 \mathrm{mM}$ PMSF). The samples were homogenised with a micropestle, and centrifuged to sediment the nuclei. The nucleus pellet was resuspended in buffer $\mathrm{C}(20 \mathrm{mM}$ HEPES $(\mathrm{pH}$ 7.9), $1.5 \mathrm{mM} \mathrm{MgCl}, 0.45 \mathrm{M} \mathrm{NaCl}, 0.2 \mathrm{mM}$ EDTA, $0.5 \mathrm{mM}$ PMSF, $0.5 \mathrm{mM}$ DTT, $20 \%$ (vol/vol) glycerol). After centrifugation, the supernatants were collected. ${ }^{30}$ Protein concentrations were determined by the Bradford method with a protein assay kit (Bio-Rad Laboratories, Hercules, CA). A gel shift assay was performed as described. ${ }^{31}$ In brief, ${ }^{32} \mathrm{P}$ labelled DNA fragments were incubated at room temperature for 15 minutes with 5 to 10 $\mu \mathrm{g}$ of nuclear protein. Protein-DNA complexes were separated from free probe on a 6 or $8 \%$ polyacrylamide gel. Thereafter, the gels were exposed to $x$ ray film. We verified that a 20 -fold excess of specific cold oligonucleotide did 


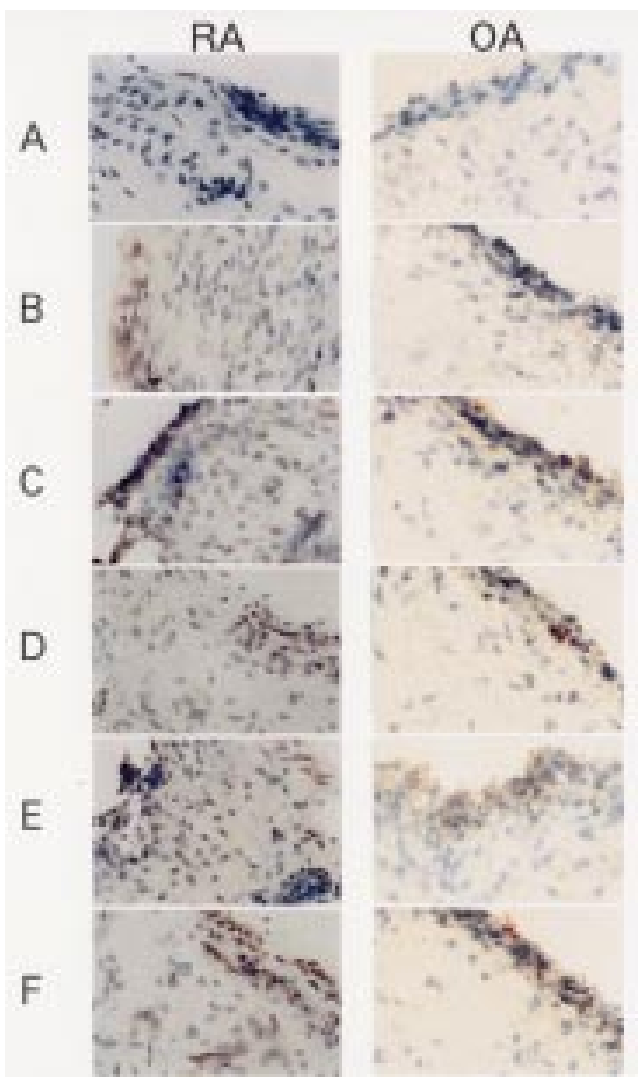

Figure 1 Immunohistochemical analysis of transcription factors expressed in the synovial tissue obtained by joint surgery of patients with $R A$. Expression of transcription factors on $R A$ and $O A$ synovial tissues was studied by immunohistochemical staining; $(A)$, control rabbit IgG; (B), NF- $\kappa B$ p 65; (C), NF- $\kappa B$ p 50; (D), c-fun; (E), CREB; $(F)$, OCT-1. These samples are from a patient with $R A$ and a patient with $O A$. It is evident that $N F-\kappa B$ p 65 , $N F-\kappa B$ p50, $c-\mathcal{F} u n, C R E B$, and OCT-1 are simultaneously expressed in $R A$ synovial tissue. OA synovial cells

contained much less transcription factors in their cytoplasm and did not express them at all in their nuclei. Results shown are representative of independent experiments using 12 patients with $R A$ and four patients with $O A$ with similar results. Control staining with non-immune mouse IgG did not stain at all, thus was omitted.

compete the binding of the protein to the ${ }^{32} \mathrm{P}$-labelled probe, whereas similar excess of unlabelled irrelevant probe did not (data not shown). Double stranded oligonucleotides including CREB binding site gATTggCTgACgTCAgAgAgCT, AP-1 binding site CTAgTgATgAgTCAgCCggATC, OCT-1 binding site gATCgAATgCAAATCACTAg$\mathrm{CT}$, and $\mathrm{NF}-\kappa \mathrm{B}$ binding site gATCgAggggACTTTCCCTAgC were obtained from Stratagene and were labelled with ${ }^{32} \mathrm{P}$ using $\mathrm{T} 4$ polynucleotide kinase. ${ }^{31}$

\section{WESTERN BLOTTING ANALYSIS}

To study expression of transcription factors, nuclear proteins were prepared. ${ }^{29} 30$ Samples were electrophoresed on a $4-20 \%$ polyacrylamide gel under reducing condition and the proteins were transferred to PVDF membranes. The membranes were incubated with the first $\mathrm{Ab}$ and biotin labelled goat antimouse IgG or antirabbit IgG $\mathrm{Ab}$, followed by peroxidase conjugated streptoavidin. Detection was carried out using ECL kit (Amersham, Arlington Heights, IL).

\section{Results}

IMUNOHISTOCHEMICAL ANALYSIS OF

TRANSCRIPTION FACTORS EXPRESSED IN THE

SYNOVIAL TISSUE OF PATIENTS WITH RA

To elucidate molecular mechanisms that are responsible for formation of the hyperplastic synovium of RA patients, we studied transcription factor expression in RA synovial tissues (fig 1). By using immunohistochemical analysis, we have detected simultaneous expression of NF- $\kappa \mathrm{B}$ p65, NF- $\kappa \mathrm{B}$ p50, c-Jun (a component of AP-1), CREB, and OCT- 1 in the synovial tissues of almost all patients with RA (fig 1).

Immunohistochemical staining for $\mathrm{NF}-\kappa \mathrm{B}$ p65 and $\mathrm{NF}-\kappa \mathrm{B}$ p50 in synovial tissue was localised predominantly to the synovial lining cells (fig 1). The subcellular localisation of the staining was predominantly in the nucleus, indicating that the NF- $\mathrm{NB}$ subunits make complexes, and were devoid of its inhibitory subunit I- $\kappa \mathrm{B}$. Hence, NF- $\kappa \mathrm{B}$ was in its activated state. Based on the histological appearance, cells positively stained with the relevant $\mathrm{Ab}$ included macrophage-like synovial cells and fibroblast-like synovial cells. Lymphocyte infiltrates, when present, were unstained (fig 1 , and data not shown).

Staining of c-Jun (AP-1), CREB, and OCT-1 were all localised within the synovial lining and intimal lining cells in RA synovial tissues, and there were at least several synovial cells whose nuclei were positively stained for the respective transcription factors (fig 1). In contrast, OA synovial cells did not express these transcription factors in their nuclei, suggesting the transcription factors were not in active form.

IMMUNOHISTOCHEMICAL ANALYSIS OF

TRANSCRIPTION FACTORS ASSOCIATED WITH FORMATION OF THE IN VITRO MACROSCOPIC TISSUE OUTGROWTH OF RA PATIENTS

As previously reported by Holoshitz et $a l,{ }^{23}$ single cell suspension of synovial cells did make cell aggregates resembling pannus after a long term in vitro culture (fig 2), and their histological feature also resembled the actual pannus of RA patients (fig 2). We consider that this is a good model for analysing requirement for development of tissue outgrowth in RA synovium in vitro. Thus we prepared macroscopic tissue outgrowth in vitro, and stained with anti-transcription factor antibodies. We

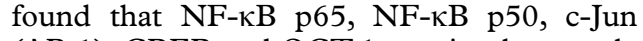
(AP-1), CREB and OCT-1 are simultaneously expressed within the nuclei of synovial cells in the in vitro tissue outgrowth in patients with RA (fig 2).

We similarly cultured synovial cells to develop in vitro tissue outgrowth resembling pannus in four patients with OA. In contrast with the RA synovial cells, we did not succeed in developing tissue outgrowth from OA synovial cells. Thus, it is suggested that simultaneous expression of multiple transcription factors are associated with the development of tissue outgrowth both in vivo and in vitro in patients with RA. 

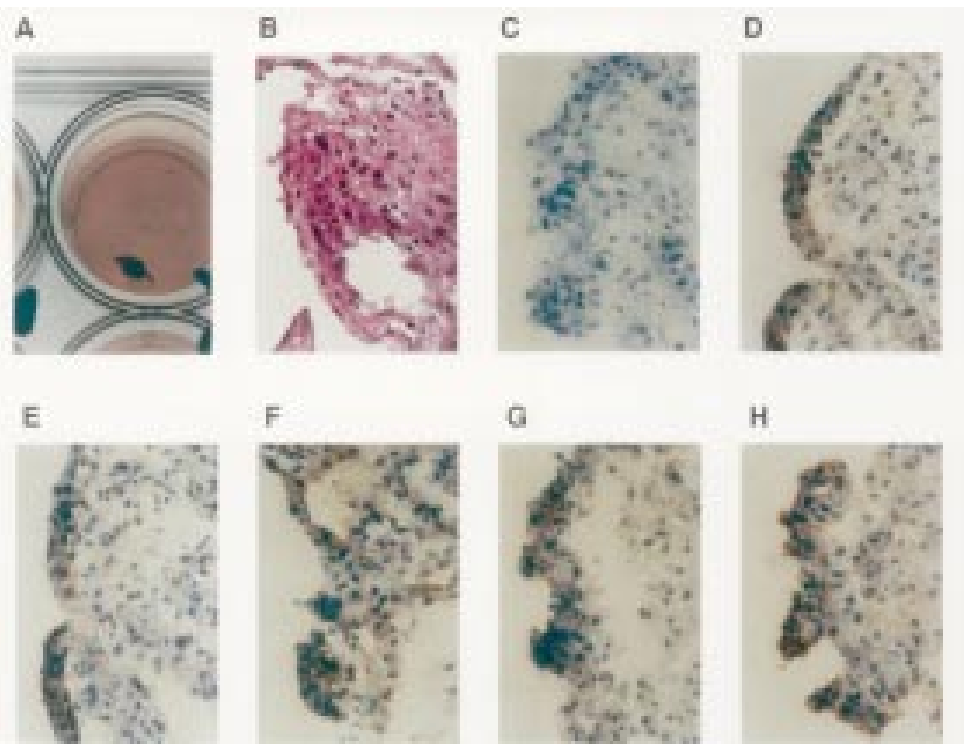

Figure 2 Analysis of macroscopic tissue outgrowth developed in vitro after a long term cultures of dissociated synovial cells. (A) Macroscopic examination of the tissue outgrowth. (B) Haematoxylin and eosin staining showed that the well organised multicellular masses have shared many microscopic features with pannus in patients with RA. Results shown are representative of total 10 independent experiments with similar results. We have not succeeded in developing tissue outgrowth from $O A$ synovial cells. $(C-H)$ Involvement of transcription factors in the formation of the in vitro macroscopic tissue outgrowth resembling pannus; (C), control rabbit IgG; (D), NF- $\kappa B$ p65; (E), NF- $\kappa B$ p50; (F), c-fun; (G), CREB; (H), OCT-1. It is evident that NF- $\kappa B$ p65, p50, $c-f u n, C R E B$, and OCT-1 are simultaneously expressed in the in vitro tissue outgrowth. Results shown are representative of total 10 independent experiments with similar results. Control staining with non-immune mouse IgG did not stain at all, thus was omitted.

GEL SHIFT ASSAY OF TRANSCRIPTION FACTORS INVOLVED IN RA SYNOVIAL CELL ACTIVITY To confirm involvement of transcription factors for the hyperfunction of RA synovial cells, we studied transcription factor expression of fibroblast-like synovial cells in patients with RA by gel shift assays, because fibroblast-like synovial cells are one of the major constituents of pannus (fig 3). Synovial fibroblast-like cells were stimulated with IL1 $\beta$, and thereafter nuclear proteins were recovered. We detected the DNA binding activity of NF- $\kappa \mathrm{B}, \mathrm{AP}-1$ (c-Jun), OCT-1, and CREB simultaneously in the nuclear proteins of the synovial cells in patients with RA. $\mathrm{NF}-\kappa \mathrm{B}$ was expressed in RA and OA synovial cells before and after IL1 $\beta$ stimulation (fig 3). However, CREB, AP-1 and OCT-1 were not expressed in OA synovial cells even after stimulation with the cytokine (fig 3). Of note was the fact that AP-1 is expressed at one hour and again at six hours after IL1 $\beta$ stimulation of RA synovial cells (fig 3), suggesting the existence of autostimulatory loop operating within the RA synovium. We found that IL1 $\beta$ stimulation induced IL6 and IL8 production by RA synovial cells (data not shown), and thus, it is possible that the cytokines, in turn, stimulate the synovial cells to express AP-1 transcription factors.

NUCLEAR TRANSLOCATION OF MULTIPLE TRANSCRIPTION FACTORS IN THE SYNOVIAL CELLS STIMULATED WITH IL1 $\beta$

It is important to further confirm that transcription factors are activated and translocated into nucleus to exert their function. To this end, we examined nuclear translocation of transcription factors preexisting within the cytoplasm in response to IL1 $\beta$ stimulation in fibroblast-like synovial cells of RA patients by using western blotting methods with transcription factor specific antibodies (fig 4). NF- $\mathrm{KB}$ p65, c-Jun, CREB, and OCT-1 proteins simultaneously translocated into the nuclei when fibroblast-like synovial cells were stimulated with IL1 $\beta$. Thus, it is evident that NF- $\mathrm{BB}$ p65, c-Jun, CREB, and OCT-1 are activated, move to their nuclei, and thus, are involved in the RA synovial cell hyperfunction.
NF-kB

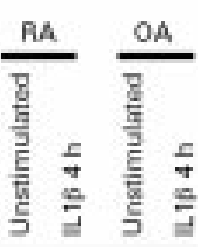

CAEB
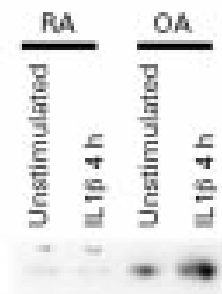

...

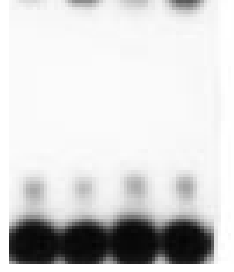

Figure 3 Gel shift assays of transcription factors involved in the RA synovial cell function. Transcription factor expression of fibroblast-like synovial cells was studied by gel shift assays in patients with $R A$ and $O A$. Synovial fibroblast-like cells were stimulated with IL $1 \beta$ and nuclear proteins were recovered. We found the expression in the nucleus of $N F-\kappa B, C R E B$, $A P-1$ (c-fun), and OCT-1 in the synovial cells in patients with $R A$. We also found that the same set of transcription factors was expressed on TNFa stimulated fibroblast-like synovial cells (data not shown). Results shown are representative of total 12 independent experiments with similar results. 


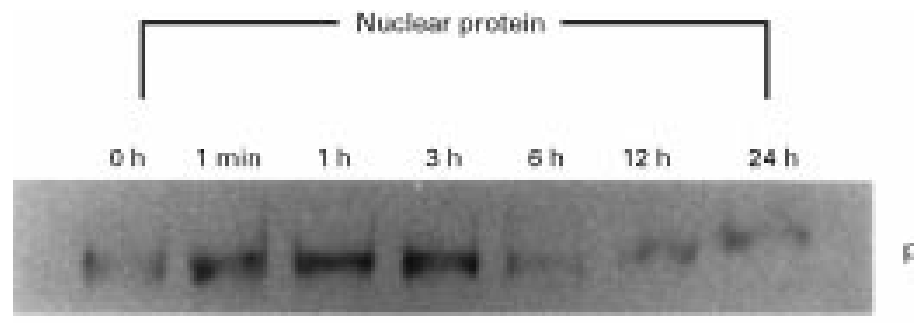

965

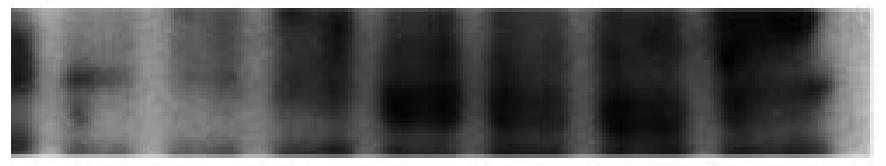

c.Jun

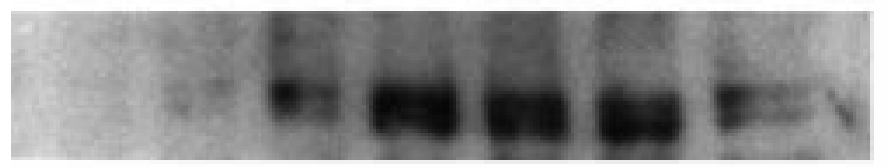

CREB

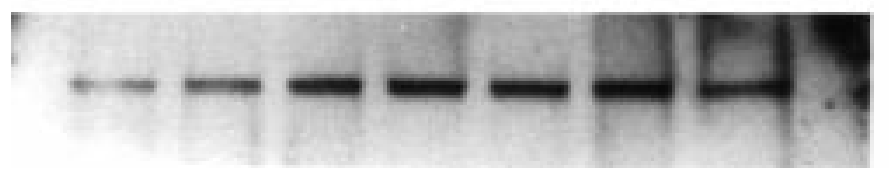

OCT-1

Figure 4 Western blotting analysis of transcription factors involved in the $R A$ synovial cell function. Transcription factor expression and their translocation into nucleus of fibroblast-like synovial cells in patients with $R A$ were studied by western blotting. Fibroblast-like synovial cells were stimulated with IL1 $\beta$ and nuclear proteins were separately recovered. We found the translocation into nucleus of $N F-\kappa B$ p65 $(65 \mathrm{kDa})$, $A P-1(c-7 u n ; 39 \mathrm{kDa}), C R E B(43 \mathrm{kDa})$, and OCT-1 (95 kDa) in the synovial cells in patients with RA. Results shown are representative of total 12 independent experiments with similar results.

EFFECTS OF VARIOUS MODULATORS OF TRANSCRIPTION FACTOR EXPRESSION ON RA SYNOVIAL CELL PROLIFERATION

To further confirm the involvement of transcription factors for the synovial cell hyperfunction, we have studied effects of various substances that modulate transcription factor expression $^{25-27}$ on RA synovial cell proliferation (fig 5). We did not include OCT-1 specific inhibitor in the experiments, because we were unable to find out such compounds. We found that NAC, an inhibitor of NF- $\mathrm{KB}$ and $\mathrm{AP}-1$; dexamethasone, an inhibitor of AP-1 and possibly NF- $\mathrm{NB}$; and Rp-cAMP, an inhibitor of cAMP/CREB pathway; inhibited synovial cell proliferation, suggesting the participation of these transcription factors for the RA synovial cell hyperfunction.

\section{Discussion}

Synovial cell hyperplasia, cell recruitment to synovium, and defective apoptosis of synovial cells are characteristic of patients with RA. Excessive proliferation of RA synovial cells is, in part, responsible for the synovial cell hyperplasia. In this study, we have studied transcription factor expression of RA synovial tissue and tissue outgrowth developed in vitro. To prepare the tissue outgrowth, we adopted the in vitro culture system originally reported by Holoshitz, where single cell suspension including infiltrating lymphocytes and synovial cells of RA synovial tissue was cultured and produced an outgrowth of an organised inflammatory tissue with extracellular matrix and capsule. ${ }^{23}$

Our study suggests that all of these transcription factors are expressed on RA synovial tissue. OA synovial cells lack expression of some transcription factors even after proinflammatory cytokine stimulation. Thus decreased expression of transcription factors may relate with the failure of establishing tissue outgrowth from $\mathrm{OA}$ synovial cells.

Our study further emphasises the importance of simultaneous expression of several transcription factors for the hyperactivity of RA synovial cells, because blocking of one transcription factor, but not simultaneous blocking
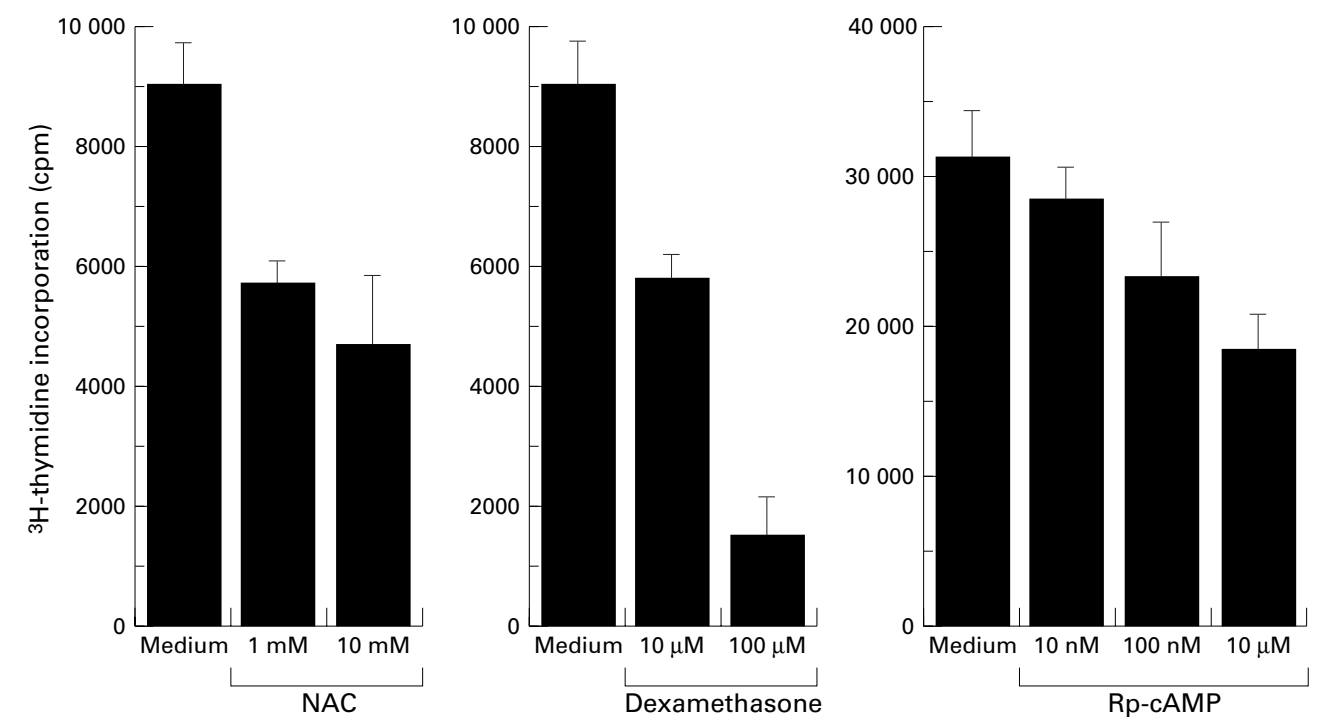

Figure 5 Effects of various modulators of transcription factor expression on $R A$ synovial cell proliferation. Effects of various substances that modulate transcription factor expression on $R A$ synovial cell proliferation induced by $10 \%$ FCS stimulation were studied by means of $\left[{ }^{3} \mathrm{H}\right]-T d R$ incorporation of $R A$ synovial fibroblast-like cells. $R A$ synovial cells were first growth arrested by culturing in IMDM $+0.25 \% \mathrm{FCS}$, and thereafter the cells were stimulated to resume growth with IMDM+10\% FCS. In the preliminary experiments, we confirmed that each compound at the highest concentrations tested in this study inhibited respective transcription factor expression. We found that NAC, dexamethasone, and $R p-c A M P$ inhibit synovial cell proliferation, suggesting the participation of the transcription factors for the RA synovial cell hyperfunction. Results shown are representative of four independent experiments with similar results. 
of multiple transcription factors, is sufficient for the inhibition of RA synovial cell proliferation (fig 5). This is true for the tissue outgrowth developed in vitro; successful development of tissue outgrowth in vitro always accompanies the expression of various transcription factors (NF-kB, c-Jun (a component of AP-1), CREB, and OCT-1) simultaneously. Collectively, NF$\kappa \mathrm{B}, \mathrm{AP}-1, \mathrm{CREB}$, and OCT-1 are simultaneously expressed within the nuclei of synovial cells to activate gene transcription in almost all patients with RA. It is possible that simultaneous expression of these transcription factors are importantly associated with in vivo tissue outgrowth in RA synovium.

There were moderate to diffuse infiltration of chronic inflammatory cells into the synovium in patients with RA. However, inflammatory cell infiltration was rather scanty in OA synovium. This finding shows that lack of lymphocyte infiltration may also be associated with the failure of developing tissue outgrowth from OA synovial cells.

We found that induction of transcription factors in vitro requires IL1 $\beta$ stimulation. It is possible that $\mathrm{T}$ lymphocyte-derived and/or macrophage-like cell derived cytokines, viral products or unidentified factors stimulate transcription factor induction of RA synovial cells in vivo by an autocrine or paracrine fashion. The resultant transcription factors induced by such cytokines, viral products or unidentified factors may lead to the constitutive proinflammatory cytokine production by RA synovial cells.

AP-1 is composed of homodimers and heterodimers of Jun and Fos proteins. ${ }^{32}$ Results of several previous studies have shown that both c-fos and c-jun are highly expressed in the RA synovium..$^{33-35}$ AP-1 pathway is involved in the transcription of several genes known to play a key part in tissue destruction. ${ }^{35-37} \mathrm{~A}$ high level of AP-1 activity may play an important part in certain aspects of the pathogenesis of RA, such as synovial hyperplasia, overproduction of tissue degrading MMP, and immunological dysfunction. ${ }^{38}{ }^{39}$ It should be noted that AP-1 transcription factor is easily induced by $\operatorname{IL} 1 \beta$ stimulation in RA synovial cells and AP-1 is not induced in the OA synovial cells that are similarly stimulated with IL1 $\beta$. Thus, increased expression of the tissue destructive proteases in RA joints ${ }^{40}$ is most probably caused by a high level of AP-1 activity in RA synovial cells.

$\mathrm{NF}-\kappa \mathrm{B}$ is involved in induction of expression of a variety of inflammatory genes. ${ }^{41}$ The DNA binding nuclear form is a heterodimer, composed of one p65 (Rel-A) and one p50 subunit. ${ }^{42}$ In unstimulated cells, NF- $\kappa \mathrm{B}$ exists in an inactive cytosolic form, bound to its inhibitor $\mathrm{I}-\kappa \mathrm{B}$. Upon stimulation, I- $\kappa \mathrm{B}$ dissociates from the NF- $\mathrm{NB}-\mathrm{I}-\kappa \mathrm{B}$ complex, and nuclear location sequences in p65 and p50 are unmasked. ${ }^{43}$ $\mathrm{NF}-\kappa \mathrm{B}$ is then translocated to the nuclei, where it controls gene expression. Expression of $\mathrm{NF}-\kappa \mathrm{B}$ in the RA synovium has been reported, ${ }^{18-20}$ in accordance with our results.

The oct genes are part of the POU domain family of regulatory genes. ${ }^{44}$ The protein products of the oct genes are capable of binding to the octamer motif present in the promoters and enhancer regions and regulate gene expression. ${ }^{45-48}$ OCT-1 has been shown to interact with a variety of tissue specific transcription factors in different tissues, including Pit-1 in the pituitary, ${ }^{49} \mathrm{OAP}$ in $\mathrm{T}$ lymphocytes, ${ }^{50}$ and viral proteins. ${ }^{51-53}$ It is of interest to clarify whether OCT-1 expressed in the RA synovial cells interacts with an unidentified synovium specific transcription factor to exert its activity or not.

Cyclic adenosine 3', 5'-monophosphate (cAMP) is one of the intracellular signalling molecules of many cell types. cAMP binds to the regulatory subunit of protein kinase $A$ and releases the active catalytic subunit. ${ }^{54}$ This subunit phosphorylates the transactivation domain of CRE-binding protein $\left({ }^{133-}\right.$ serine of CREB), which then induces the expression of genes containing CREs. ${ }^{55-60}$ Beside ${ }^{133-}$ serine phosphorylation of CREB, we found that activation of synovial cells accompanies nuclear translocation of CREB (fig 4) and CRE binding activity (fig 3 ). Thus, our study shows that CREB and OCT-1, in addition to the $\mathrm{NF}-\kappa \mathrm{B}$ and $\mathrm{AP}-1$, are induced and may be involved in the synovial cell activity of RA patients.

It should be emphasised that AP-1 activity was detected twice (one hour and six hours after stimulation with IL1 $\beta$ ) in the nuclear proteins of IL1 $\beta$ stimulated synovial cells by gel shift assays. It is possible that IL $1 \beta$ stimulated synovial cells secrete another proinflammatory cytokine, and the cytokine in turn stimulates the synovial cells, acting as autostimulatory loop within the synovium. Indeed, we have detected IL6 and IL8 production by IL1 $\beta$ stimulated fibroblast-like synovial cells in patients with RA (data not shown).

We found that SP-1 was not expressed in RA and OA synovial cells after IL1 $\beta$ stimulation, and that AP-2 was induced in RA and OA synovial cells with similar kinetics (data not shown). We interpret these findings that these two transcription factors are not likely to play an important part in RA synovial cell hyperfunction. There are several reports that described involvement of a transcription factor in the pathogenesis of RA. However, none has reported the involvement of multiple transcription factors in the pathogenesis.

In this study, we used NAC, cAMP analogue, and glucocorticosteroid for modulating transcription factor activities. NAC is an antioxidant that affects not only NF- $\kappa \mathrm{B}$, but also AP-1 activities in various cell types. ${ }^{6162}$ Dexamethasone has been shown to modulate $\mathrm{NF}-\kappa \mathrm{B}$ activity (this may or may not be because of induction of I- $\kappa \mathrm{B}$ production) and AP-1 activity. ${ }^{63-65}$ It has recently been postulated that disease modifying anti-rheumatic drugs (DMARDs) including gold sodium thiomalate and D-penicillamine affect transcription factor activity. ${ }^{66}$ However, it should be borne in mind that the inhibitors used in this study may have other functions that could be inhibiting synovial cell hyperfunction other than blocking these specific transcription factors. Dexamethasone can have global effects 
on cellular function that could be mediated through other mechanisms than inhibiting transcription factors. Nevertheless, modulation by new agents of transcription factors would become a promising candidate for treating patients with RA. We have also studied the effects of various transcription factor inhibitors on metalloproteinase production and IL6 production of RA synovial cells. We found that NAC, cAMP analogue, and glucocorticosteroid inhibited production of collagenase and IL6 by RA synovial cells (S Wakisaka et al, unpublished data) further confirming involvement of transcription factors for the RA synovial cell hyperfunction.

In summary, we found that coordinated expression of several transcription factors may be associated with the synovial cell hyperfunction in patients with RA, and modulation of the transcription factors would inhibit RA synovial cell hyperfunction. Although blocking of a transcription factor is sufficient for inhibiting synovial cell hyperfunction in vitro, we are now studying effects of combination of distinct inhibitors of transcription factors for controlling RA synovial cell activity more efficiently.

We thank Dr Hirotaka Koizumi, Department of Pathology, St Marianna University School of Medicine for his excellent technical assistance.

1 Harris ED Jr. Rheumatoid arthritis: pathophysiology and implications for therapy. N Engl J Med 1990;322:1277-89. Cash JM, Klippel JH. Second-line drug therapy for rheumatoid arthritis. N Engl J Med 1994;330:1368-75.

3 Panayi GS, Lanchbury JS, Kingsley GH. The importance of the $\mathrm{T}$ cell in initiating and maintaining the chronic synovitis of rheumatoid arthritis. Arthritis Rheum 1992;35:72935.

4 McCarty DJ, Koopman WJ, eds. Arthritis and allied conditions: a text book of rheumatology. 12th ed. Philadelphia: Lea and Febiger, 1993.

5 Dayer J-M, de Rochemonteix B, Burrus B, Demczuk S, Dinarello CA. Human recombinant interleukin 1 stimulates collagenase and prostaglandin E2 production by human synovial cells. J Clin Invest 1986;77:645-8.

6 Qu Z, Garcia CH, O'Rourke LM, Planck SR, Kohli M, Rosenbaum JT. Local proliferation of fibroblast-like synoviocytes contributes to synovial hyperplasia: results of synoviocytes contributes to synovial hyperplasia: results of
proliferating cell nuclear antigen/cyclin, c-myc, and nucleoproliferating cell nuclear antigen/cyclin, c-myc, and nucleo212-20.

7 Firestein GS. Invasive fibroblast-like synoviocytes in rheumatoid arthritis: passive responders or transformed aggressors? Arthritis Rheum 1996;39:1781-90

8 Arend WP, Dayer J-M. Cytokines and cytokine inhibitors or antagonists in rheumatoid arthritis. Arthritis Rheum 1990; 33:305-15.

9 Bucala R, Ritchlin C, Winchester R, Cerami A. Constitutive production of inflammatory and mitogenic cytokines by 74.

10 Muller Ladner U. Molecular and cellular interactions in rheumatoid synovium. Curr Opin Rheumatol 1996;8:21020 .

11 Sakai M, Eguchi K, Terada K, Nakashima M, Yamashita I, Ida $\mathrm{H}$, et al. Infection of human synovial cells by human $\mathrm{T}$ cell lymphotropic virus type I. Proliferation and granulocyte/macrophage colony-stimulating factor producgranulocyte/macrophage colony-stimulating factor pro
tion by synovial cells. J Clin Invest 1993;92:1957-66.

12 Pronost S, Redini F, Vivien D, Galera P, Pujol JP. Human rheumatoid synovial cells (HRSC) in culture express TGF- $\beta$ receptors and are growth stimulated by the factor. Agents Actions Suppl 1993;39:133-7.

13 Sewall CH, Bell DA, Clark GC, Tritscher AM, Tully DB, Van den Heuvel J, et al. Induced gene transcription: implications for biomarkers. Clin Chem 1995;41:1829-34.

14 Lofquist AK, Mondal K, Morris JS, Haskill JS. Transcription-independent turnover of I $\mathrm{I}$ B $\alpha$ during monocyte adherence: implications for a translational com-
ponent regulating I $\mathrm{B} \alpha / \mathrm{MAD}-3$ mRNA levels. Mol Cell Biol 1995;15:1737-46.

15 Gudi T, Huvar I, Meinecke M, Lohmann SM, Boss GR, Pilz $\mathrm{RB}$. Regulation of gene expression by cGMP-dependent protein kinase: transactivation of the c-fos promoter. J Biol Chotein kinase: transactivation

16 Zitnik RJ, Whiting NL, Elias JA. Glucocorticoid inhibition of interleukin-1-induced interleukin-6 production by of interleukin-1-induced interleukin- 6 production by post-transcriptional regulatory mechanisms. Am J Respir post-transcriptional regulatory
Cell Mol Biol 1994;10:643-50.
$17 \mathrm{Gu}$ W, Cechova K, Tassi V, Dalla-Favera R. Opposite reguation of gene transcription and cell proliferation by c-Myc and Max. Proc Natl Acad Sci USA 1993;90:2935-9.

18 Marok R, Winyard PG, Coumbe A, Kus ML, Gaffney K, Blades S, et al. Activation of the transcription factor nuclear factor- $\kappa \mathrm{B}$ in human inflamed synovial tissue. Arthritis Rheum 1996;39:583-91.

19 Handel ML, McMorrow LB, Gravallese EM. Nuclear factor- $\kappa \mathrm{B}$ in rheumatoid synovium: localization of p50 and p65. Arthritis Rheum 1995;38:1762-70.

20 Fujisawa K, Aono H, Hasunuma T, Yamamoto K, Mita S, Nishioka $\mathrm{K}$. Activation of transcription factor NF- $\kappa \mathrm{B}$ in human synovial cells in response to tumor necrosis factor $\alpha$. Arthritis Rheum 1996;39:197-203

21 Asahara H, Fujisawa K, Kobata T, Hasunuma T, Maeda T, Asanuma $\mathrm{M}$, et al. Direct evidence of high DNA binding activity of transcription factor AP-1 in rheum
synovium. Arthritis Rheum 1997;40:912-18.

22 Arnett FC, Edworthy SM, Bloch DA, McShane DJ, Fries $\mathrm{JF}$, Cooper NS, et al. The American Rheumatism Association 1987 revised criteria for the classification of rheumatoid arthritis. Arthritis Rheum 1988;31:315-24.

23 Holoshitz J, Kosek J, Sibley R, Brown DA, Strober S. T lymphocyte-synovial fibroblast interactions induced by mycobacterial proteins in rheumatoid arthritis. Arthritis Rheum 1991;34:679-86.

24 Martel-Pelletier J, Cloutier J-M, Pelletier J-P. In vivo effects of antirheumatic drugs on neutral collagenolytic proteases in human rheumatoid arthritis cartilage and synovium. J Rheumatol 1988;15:1198-204.

25 Sakurada S, Kato T, Okamoto T. Induction of cytokines and ICAM-1 by proinflammatory cytokines in primary rheumatoid synovial fibroblasts and inhibition by $\mathrm{N}$-acetyl-Lcysteine and aspirin. Int Immunol 1996;8:1483-93.

26 Tessier PA, Cattaruzzi P, McColl SR. Inhibition of lymphocyte adhesion to cytokine-activated synovial fibroblasts by glucocorticoids involves the attenuation of vascular cell adhesion molecule 1 and intercellular adhesion molecule 1 gene expression. Arthritis Rheum 1996;39: 226-34.

27 Wang L-Y, Taverna FA, Huang X-P, MacDonald JF, Hampson DR. Phosphorylation and modulation of a kainate receptor (GluR6) by cAMP-dependent protein kinase. Science 1993;259:1173-5.

28 Sakane T, Suzuki N, Hirose Y, Miura K, Wakisaka K, Nagafuchi $\mathrm{H}$, et al. Mechanisms of KE298, 2-acetylthiomethyl-3-(4-methylbenzoyl) propionic acid, to suppress abnormal synovial cell functions in human rheumatoid arthritis. J Rheumatol 1997;24:2213-20.

29 Dignam JD, Lebovitz RM, Roeder RG. Accurate transcription initiation by RNA polymerase II in a soluble extract from isolated mammalian nuclei. Nucleic Acids Res 1983; 11:1475-89.

30 Angel P, Imagawa M, Chiu R, Stein B, Imbra RJ, Rahmsdorf HJ, et al. Phorbol ester-inducible genes contain a common Cis element recognized by a TPA-modulated Trans-acting factor. Cell 1987;49:729-39.

31 Sambrook J, Fritsch EF, Maniatis T. Molecular cloning, a laboratory manual. 2nd ed. Cold Spring Harbor: Cold Spring Harbor Laboratory Press, 1989.

32 Angel P, Allegretto EA, Okino ST, Hattori K, Boyle WJ, Hunter T, et al. Oncogene jun encodes a sequence-specific

Angel P, Karin M. The role of Jun, Fos and the AP-1 complex in cell-proliferation and transformation. Biochim Bioplex in cell-proliferation and tran

34 Trabandt A, Aicher WK, Gay RE, Sukhatme VP, Fassbender HG, Gay S. Spontaneous expression of immediately-early response genes c-fos and egr-1 in immediately-early response genes c-fos and egr-1 in collagenase-producing rheumat

35 Muller-Ladner U, Kriegsmann J, Gay RE, Gay S. Oncogenes in rheumatoid arthritis. Rheum Dis Clin North Am 1995;21:675-90.

36 Lafyatis R, Kim S-J, Angel P, Roberts AB, Sporn MB, Karin $\mathrm{M}$, et al. Interleukin-1 stimulates and all-trans-retionic acid inhibits collagenase gene expression through its 5 ' activator protein-1-binding site. Mol Endocrinol 1990;4:973-80.

37 Mauviel A. Cytokine regulation of metalloproteinase gene expression. J Cell Biochem 1993;53:288-95.

38 Jonat C, Rahmsdorf HJ, Park K-K, Cato ACB, Gebel S, Ponta $\mathrm{H}$, et al. Antitumor promotion and antiinflammation: down-modulation of AP-1 (Fos/Jun) activity by glucocorticoid hormone. Cell 1990;62:1189204.

39 Lin A, Frost J, Deng T, Smeal T, Al-Alawi N, Kikkawa U, et al. Casein kinase II is a negative regulator of c-Jun DNA binding and AP-1 activity. Cell 1992;70:777-89.

40 Gravallese EM, Darling JM, Ladd AL, Katz JN, Glimcher LH. In situ hybridization studies of stromelysin and collagenase messenger RNA expression in rheumatoid synovium. Arthritis Rheum 1991;34:1076-84.

41 Baeuerle PA. The inducible transcription activator NF- $\kappa B$ : regulation by distinct protein subunits. Biochim Biophys Acta $1991 ; 1072: 63-80$.

42 Henkel T, Machleidt T, Alkalay I, Krönke M, Ben-Neriah Y, Baeuerle PA. Rapid proteolysis of I $\mathrm{I} B-\alpha$ is necessary for activation of transcription factor NF-אB. Nature 1993;365: 182-5.

43 Zabel U, Henkel T, dos Santos Silva M, Baeuerle PA.

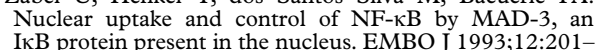
11 . 
44 Herr W, Sturm RA, Clerc RG, Corcoran LM, Baltimore D, Sharp PA, et al. The POU domain: a large conserved region in the mammalian pit-1, oct-1, oct-2, and Caenorhabditis

elegans unc-86 gene products. Genes Dev 1988;2:1513-16.
Rosenfeld MG. POU-domain transcription factors: pou-erRosenfeld MG. POU-domain transcription factors: pou-er-
ful developmental regulators. Genes Dev 1991;5:897-907.

46 Verriizer CP, Van der Vliet PC. POU domain transcription factors. Biochim Biophys Acta 1993;1173:1-21.

47 Fletcher C, Heintz N, Roeder RG. Purification and characterization of OTF-1, a transcription factor regulating cell cycle expression of a human histone H2b gene. Cell 1987; 51:773-81

48 Tanaka M, Grossniklaus U, Herr W, Hernandez N. Activation of the U2 snRNA promoter by the octamer motif defines a new class of RNA polymerase II enhancer elements. Genes Dev 1988;2:1764-78.

49 Voss JW, Wilson L, Rosenfeld MG. POU-domain proteins Pit-1 and Oct-1 interact to form a heteromeric complex and can cooperate to induce expression of the prolactin promoter. Genes Dev 1991;5:1309-20.

50 Ullman KS, Flanagan WM, Edwards CA, Crabtree GR Activation of early gene expression in $\mathrm{T}$ lymphocytes by Oct-1 and an inducible protein, OAP40. Science 1991; 254:558-62

51 Gerster T, Roeder RG. A herpesvirus trans-activating protein interacts with transcription factor OTF-1 and other cellular proteins. Proc Natl Acad Sci USA 1988;85:6347-51.

52 Stern S, Tanaka M, Herr W. The Oct-1 homoeodomain directs formation of a multiprotein-DNA complex with the HSV transactivator VP16. Nature 1989;341:624-30

53 Verrijzer CP, Kal AJ, Van der Vliet PC. The DNA binding domain (POU domain) of transcription factor oct-1 suffices for stimulation of DNA replication. EMBO J 1990; 9:1883-8.

54 Ji L, Mochon E, Arcinas M, Boxer LM. CREB proteins function as positive regulators of the translocated bcl-2 allele in t(14;18) lymphomas. J Biol Chem 1996;271:22687-91.

55 Dash PK, Karl KA, Colicos MA, Prywes R, Kandel ER. cAMP response element-binding protein is activated by $\mathrm{Ca} 2+/$ calmodulin-as well as cAMP-dependent protein kinase. Proc Natl Acad Sci USA 1991;88:5061-5.
56 Sheng M, Thompson MA, Greenberg ME. CREB: a Ca2+regulated transcription factor phosphorylated by 30 .

57 Yamamoto KK, Gonzalez GA, Biggs WH III, Montminy MR. Phosphorylation-induced binding and transcriptional efficacy of nuclear factor CREB. Nature 1988;334:494-8.

58 Lalli E, Sassone-Corsi, P. Signal transduction and gene regulation: the nuclear response to cAMP. J Biol Chem 1994;269:17359-62.

59 Lee KAW, Masson N. Transcriptional regulation by CREB and its relatives. Biochim Biophys Acta 1993;1174:221-33.

60 Meyer TE, Habener JF. Cyclic adenosine 3', 5'monophosphate response element binding protein (CREB) and related transcription-activating deoxyribonucleic acidbinding proteins. Endocr Rev 1993;14:269-90.

61 Abate C, Patel L, Rauscher FJ III, Curran T. Redox regulation of Fos and Jun DNA-binding activity in vitro. Science 1990;249:1157-61.

62 Tanaka C, Kamata H, Takeshita H, Yagisawa H, Hirata H. Redox regulation of lipopolysaccharide (LPS)-induced interleukin-8 (IL-8) gene expression mediated by NFKB and AP-1 in human astrocytoma U373 cells. Biochem Biophys Res Commun 1997;232:568-73.

63 Liden J, Delaunay F, Rafter I, Gustafsson J, Okret S. A new function for the C-terminal zinc finger of the glucocortifunction for the C-terminal zinc finger of the glucocorticoid receptor. Repression of
Chem 1997;272:21467-72.

64 Heck S, Bender K, Kullmann M, Gottlicher M, Herrlich P, Cato AC. I $\kappa \mathrm{B} \alpha$-independent down-regulation of NF- $\kappa \mathrm{B}$ activity by glucocorticoid receptor. EMBO J 1997;16: 4698-707.

65 Vayssiere BM, Dupont S, Choquart A, Petit F, Garcia T, Marchandeau C, et al. Synthetic glucocorticoids that dissociate transactivation and AP-1 transrepression exhibit antiinflammatory activity in vivo. Mol Endocrinol 1997:11: 1245-55.

66 Handel ML. Transcription factors AP- 1 and NF- $\kappa \mathrm{B}$. where steroids meet the gold standard of anti-rheumatic drugs. Inflamm Res 1997;46:282-6. 